\title{
QUALITY OF HOTEL SERVICES - SELECTED ISSUES
}

\author{
DANIEL SZOSTAK
}

University of Szczecin, Faculty of Earth Sciences, POLAND

e-mail: daniel.szostak@wp.pl

RECEIVED
ACCEPTED
JEL
CLASSIFICATION

KEYWORDS

ABSTRACT
10 December 2018

28 December 2018

D21

hospitality, quality, hotel service, quality management in hotel busines

The paper presents problems connected with quality relationship between hotels and theirs clients. The article discusses the most important aspects of the quality of hotel services. Method: Descriptive method. Basic conditions of the development of contemporary tourism is how to provide a suitable hotel product to clients witch wants consume a perfect tourism service. The research into consumption in world tourism shows that prices, quality of products and the condition of the natural environment are playing, and in the future will play, a decisive role in the choice of destinations by tourists. Quality is a very important element of each product: good and service. Hotels must concentrate on many elements for creating high level of quality. The quality of hotel services can be discussed, on the one hand, from the point of view of the service provider as a standard of service based on experience and forced externally, that is - a collection of characteristics that a given service should possess in order to fully satisfy the needs of a hotel guest with regard to accommodation and food. On the other hand, the quality of services is perceived individually by the customers, who define it as the difference between what they expect and a subjective judgment of what they receive.

\section{Introduction}

The research into consumption in world tourism shows that prices, quality of products and the condition of the natural environment are playing, and in the future will play, a decisive role in the choice of destinations by tourists. Therefore, hotel enterprises must accurately identify the needs and expectations of their customers. The specificity of hotel services lies in the direct contact and specific relations between the hotel staff and the guests. However, the 
hotel operator's personnel do not always use their knowledge in order to raise the quality of their services and, in consequence, to raise the quality of customer service. The reasons for this might be many and various, e.g. a lack of awareness among the personnel of how important it is to know the customers and know how to provide them with quality service, a lack of interest on the part of hotel managers, a lack of proper and well-functioning information channels within and without the hotel, a lack of a data gathering and processing system. By implementing carefully planned pro-quality actions the abovementioned reasons can be eliminated - the first two by implementing an effective training system, the other through appropriate organization and management and accurate description of processes within the hotel facility (Szostak, 2004, p. 75).

\section{The quality of service}

The quality of service cannot be defined without considering the essence of service itself, i.e. the characteristics that define its very nature, that is, e.g. its immateriality, unity of production and consumption, variety (difficulty of carrying out universal standardization). The quality of hotel services can be discussed, on the one hand, from the point of view of the service provider as a standard of service based on experience and forced externally, that is - a collection of characteristics that a given service should possess in order to fully satisfy the needs of a hotel guest with regard to accommodation and food. On the other hand, the quality of services is perceived individually by the customers, who define it as the difference between what they expect and a subjective judgment of what they receive. Customers usually analyze how much the service lives up to their expectations, at the same time comparing it with their acceptable price level. The bigger the gap, the greater the customer's dissatisfaction, which in consequence can make the customer decide not to use the services of the given provider or even not to use this type of services at all. In many cases the price is the indicator of quality, e.g. the higher the hotel's category, the higher the price of hotel services, and the level of prices is commonly accepted. The willingness to use more expensive services depends solely on the customer and his purchasing power. Similar assumptions can be made with regard to catering facilities. In the case of hotel facilities with a proper category or functioning within a given hotel system, the customer knows in advance what quality of service he should receive. Such an approach to the quality of hotel services originates from the tradition of the Polish and world hotel industry, the development of which is largely dependent on providing services of certain quality standards (Brown, 2003, pp. 46-48).

\section{Hotel service quality}

The consumer of hotel services judges the quality of service not only on the basis of the end result in the form of the benefits purchased, but also on the basis of how the service is provided. The first contact personnel is of utmost importance in hotel enterprises (e.g. receptionists, waiters, maids) and their skills determine the professionalism and atmosphere in which the services are used by customers as well as the end result in the form of customer satisfaction or dissatisfaction with the service (Dominik, 2012, pp. 107-117). One of the rules of interpersonal communication says that a well-served and satisfied customer will tell three other potential customers about his experiences, while one unhappy customer will inform seven other potential customers. Through appropriate customer service in modern hotel industry it is necessary to skillfully influence the perception of the hotel guest (how he perceives the services) in respect of how he perceives the sub-services of the accommodation, which is mainly a result of permanent comparisons of individual and particular expectations of the guest with the reality he 
runs into at a given hotel facility. In modern hotel industry the cost of attracting new customers is five times higher than the cost of increasing the quality of services in order to keep current customers who have stayed at the hotel more than once. Quality becomes the element that lets the hotel stand out, irrespective of the type and category, from other hotel facilities that offer similar or substitution services. If the quality of service is at an appropriate level, accepted by the customers, those customers will, as hotel guests, become regular customers. This leads to the following conclusions:

a) a regular customer is willing to pay a higher price for higher quality, because he has already purchased services at a given hotel and restaurant and was satisfied;

b) regular customers provide the company with free "word-of-mouth" advertising by telling about the level of service and their satisfaction with the end result (Kowalik, 2003, pp. 17-18).

So two basic elements of the organization and management system influence the level of quality and the process of providing quality in a hotel facility:

- the process of providing hotel services (a guest's stay at the hotel),

- the end result of the service provided (satisfaction or dissatisfaction of the guest after leaving the hotel).

In view of the above, in the case of hotels functioning in the modern tourism market, an important action towards maintaining or increasing the quality of accommodation services provided is the ability to synchronize technical quality, i.e. the fixtures and fittings of the facility and the qualifications of the personnel with functional quality, i.e. the manner of delivering the service, e.g. the personnel's behavior, communicative skills, professional attitude and ability to understand the needs of guests. It can be assumed that the quality of services provided is directly related to the profitability and competitiveness of modern hotel facilities. Economic practice in modern hotel industry shows that common examples of pro-quality routines include developing and implementing individual reception standards for each hotel or chain, catering standards, floor service standards. In many hotels such standards regulate procedures for customer service, appearance (uniforms) of receptionists and various customer service personnel, code of conduct in particular situations at work, equipment of work stations. Such standards are systematically monitored and amended as necessary in order to raise the quality of customer service and enhance the functionality of the rooms and facilities for guests at the hotel. The standard and manner of customer service are influenced by many external factors connected to new needs, such as:

- more and more customers expect non-smoking rooms; separate floors for non-smokers are prepared at hotels, and in restaurants - special areas or even whole rooms,

- a hotel should be accessible by disabled people; for that reason many hotels and restaurants convert their facilities, e.g. lower part of the reception desk for people moving in wheelchairs or for exceptionally short people, install speakerphones, widen doorways, eliminate architectural barriers (e.g. remove doorsills, build ramps).

In the case of hotel services, a few universal quality demands may be specified and identified, such as:

- reliable performance, where a reliable hotel always provides its services appropriately and professionally and keeps the promise that it will deliver the right service at the right time,

- speedy service, which is related to the readiness of the hotel's or restaurant's personnel to provide a given service, which consists in prompt and accurate performance of actions that make up the process of providing the service (this is particularly significant in the case of meals served in catering enterprises), 
- confidence and professional attitude on the part of the personnel, which is made up of the knowledge and skills of the direct customer service personnel, the company's reputation, personality of the personnel, confidence in the company, etc.,

- individual approach to customers, which consists in, among other things, the ability to recognize regular customers, remembering their detailed requirements, individualizing the manner of providing services; individual approach to customers should make the hotel guests feel like home.

An important tool for shaping the quality of services in a hotel enterprise is the implementation, especially in international hotel chains, of the Total Quality Management (TQM) system in which ass the tangible and intangible assets of the enterprise influence the quality of products and internal as well as external processes. Therefore both the quality of those products and processes and the quality of the assets (resources) of the enterprise should be embraced by management functions. TQM is one of the ways of effective management of a hotel enterprise, focused on quality, based on the participation of every member of the enterprise and looking for achieving longlasting success through customer satisfaction and benefits for all members of the enterprise. In a hotel enterprise, TQM consists of three significant elements, i.e. focus on the customer's needs, an integrated way of thinking and cooperation between all members of the enterprise. TQM is mainly a type of organizational culture of the enterprise, based on teamwork ability. It is a philosophy of how a hotel enterprise functions more than a management technique that can be introduced by issuing a directive or taken over from other enterprises (Panasiuk, Szostak, 2008, pp. 266-276).

The economic conditions for creating a system of pro-quality actions in a hotel depend, in the fundamental aspect of the problem, on the following factors:

a) type of building, its construction standard, development of the surrounding area;

b) the size, number and type of rooms, types of fittings, technical and service equipment;

c) furniture and other movables;

d) kind and quality of materials used in hotel rooms and catering facilities;

e) type and category of the catering facility functioning within the hotel;

f) type and scope of services provided by the hotel apart from the basic services: accommodation and catering;

g) the range and quality of dishes and drinks served in the hotel's catering facilities;

h) the number of personnel, their vocational qualifications, skills in foreign languages, service-providing skills;

i) organization, rules and procedures for dealing with specific situations, standards of service.

One of the main rules of the hotel industry is care about the well-being of the guests during their stay at the hotel, and that is why serving the guests is the most important task for all the personnel, irrespective of their job. So, the tourist coming to a hotel is not a mere consumer or customer, but a guest. He expects more than the basic service he has paid for, that is high quality of service, professional attitude, kindness, respect, a nice, family atmosphere. Some guests prefer smaller hotels where the personal care of every staff member about the guests and their needs is clearly noticeable and the guests' requirements and habits are treated with respect. In large hotels with extended internal structure, there are special sections responsible for maintaining good relationship between the hotel and guests, known as guest relations or specially trained staff members referred to as consierge (Pląder, 2001, pp. 11-14). 
The quality of hotel service is not simply an arithmetic sum of the particular components of the product, but a positive appraisal (satisfaction) of each of them by the guests. A hotel guests renting e.g. an accommodation unit expects certain comfort, and specifically, most of all:

- thermal comfort (appropriate temperature, ventilation, air conditioning),

- acoustic comfort (isolation and protection from noises, loud music, street noise),

- lighting comfort (appropriate natural and artificial lighting),

- sanitary comfort (appropriately furnished and equipped sanitary facilities),

- safety comfort (fire safety, security of the building and possessions left in the room etc.)

The perfection of a hotel enterprise from the point of view of quality is mostly determined by such elements as:

- good reputation of the quality of service,

- honesty of personnel at all levels of management,

- orientation towards customers and sales (e.g. linking customer satisfaction with personnel satisfaction),

- good quality of the hotel's product, as high quality services sell better than low quality services,

- using appropriate means (tools) to motivate customers to buy (e.g. qualified and competent personnel, clean restrooms),

- appropriate personnel remuneration system connected with effectiveness of work (Wolak, 2003, p. 1).

The process of adjusting the furnishings to the needs of today's hotel guests and providing them with comfortable rest night and day is so dynamic that the categorizing and standardizing requirements of many modern hotels cannot keep pace (Borkowski, Wszendobył, 2011, pp. 30-31).

\section{Conclusions}

Quality becomes necessity for many hotel operators whose most important goal is to be present in the national and international tourism market through:

- increasing the attractiveness of their accommodation through constantly increasing standards and keeping the standards at the European level,

- determining their place in categorization groups (Jaremen, 2005, pp. 155-172),

- working along a schedule of short-term and long-term undertakings in creating appropriate pro-quality policy,

- determining the specificity of their own accommodation and their target markets.

Raising the standards of furnishing and service, and then keeping those at an appropriate level accepted by the customers should pertain to all service sections and units that are fundamentally important from the point of view of the nature and specificity of hotel accommodation (in hotels, motels and guesthouses).

\section{References}

Borkowski, S., Wszendobył, E. (2007). Jakość i efektywność usług hotelarskich. Warszawa: Wydawnictwo Naukowe PWN.

Brown, S.A. (2003). Strategiczne podejście do klientów. Warszawa: PWE.

Dominik, P. (2012). Jakość obsługi gościa jako istotna determinanta powodzenia w świadczeniu usługi hotelarskiej w dobie silnej konkurencji na rynku. Ekonomia i Zarządzanie, 4 (3), 107-117.

Jaremen, D.E. (2005). Kategoryzacja obiektów hotelarskich i jej znaczenie w procesie doskonalenia jakości usług hotelarskich. In: K. Wajda (ed.), Czynniki determinujące jakość a doskonalenie systemu informacyjnego w branży turystycznej. Kraków: Wydawnictwo Uniwersytetu Jagiellońskiego. 
Kowalik, A. (2003). Nagroda za wierność. Hotelarz, 5, 18.

Panasiuk, A., Szostak, D. (eds.) (2008). Hotelarstwo. Usługi-eksploatacja-zarządzanie. Warszawa: Wydawnictwo Naukowe PWN.

Pląder, D. (ed.) (2001). Organizacja pracy w hotelarstwie. Kraków: Krakowska Szkoła Hotelarska.

Szostak, D. (2004). Podstawy hotelarskich. Materiały do ćwiczeń i wykładów. Szczecin: Wydawnictwo Naukowe Uniwersytetu Szczecińskiego.

Wolak, G. (2003). Jak rodziła się kategoryzacja i standaryzacja w polskim hotelarstwie - vol. III. Doradca Hotelarza, 1, 1.

Cite this article aS: Szostak, D. (2018). Quality of hotel services - selected issues. European Journal of Service Management, 4 (28/2), 479-484. DOI: 10.18276/ejsm.2018.28/2-57. 